\title{
ABLATION EFFEGTS DUE TO WIND-BLOWN DUST
}

\author{
By G. Hattersley-Smith \\ (Geophysics Section, Defence Research Board, Ottawa, Canada)
}

In the spring of 1960 , the Canadian I.G.Y. camp on Gilman Glacier, one of the southwardflowing outlets of the ice cap of northern Ellesmere Island, ${ }^{\mathrm{T}}$ was reoccupied from 22 May to 12 June. During the latter part of this period the role of wind-blown dust in promoting the ablation of surface snow was strikingly apparent. The following, mainly qualitative observations seem worth recording.

The camp was situated in the ablation area of Gilman Glacier at a height of $1,040 \mathrm{~m}$. In the general area of the camp on 22 May, the snow was fairly uniform in depth and only moderately wind-packed, no bare ice was visible, and there were few drifts. On 23-24 May a northerly blizzard prevailed, with winds up to $16 \mathrm{~m}$. $/ \mathrm{sec}$.; snow conditions on the glacier below the I,200 metre level were transformed. In some areas, particularly on the north-east side, the snow was completely stripped from the glacier; elsewhere the snow was compacted into drifts and skavler. A good deal of snow was blown off the glacier to ice-free marginal areas. The ice dome visible in Figure I was stripped of snow over about four-fifths of its area, the remaining snow being compacted into hard wind-slab, $10-25 \mathrm{~cm}$. thick.

The blizzard deposited a layer of wind-blown particles and small flakes of rock from nearby nunataks over much of the surface of the glacier. The rock material was scattered fairly uniformly through the very hard, wind-packed snow in the drifts and skavler; the rock particles had a mean diameter of about $0.5 \mathrm{~mm}$.; particles up to $\mathrm{I} \mathrm{mm}$. in diameter were common, and a few slaty fragments up to $3 \mathrm{~mm}$. in length were observed. In general, the drifts had the form of low domes, roughly circular or oval-shaped in plan, with the snow $20-30 \mathrm{~cm}$. deep near the middle; in most drifts the top $10-15 \mathrm{~cm}$. of snow had been deposited by the blizzard, and had a density of 0.45 to 0.50 g.cm. ${ }^{-3}$. The marbled surfaces of the drifts were marked by low ripples a few centimetres apart. One of the larger oval-shaped drifts had axes measuring 17 by $14 \mathrm{~m}$. with the longer axis running across the glacier; near the margin on the windward or up-glacier side there were $20 \mathrm{~cm}$. high skavler; near the middle the snow was I I0 $\mathrm{cm}$. deep, with very hard wind-packed snow in the upper $75 \mathrm{~cm}$. probably deposited by the May blizzard.

The rock material in the snow aided the early onset of ablation by decreasing the albedo of the snow surface. The 1960 spring was abnormally warm, so that ablation at the $1,040 \mathrm{~m}$. level was in progress by I June, a full ten days earlier than in the previous three years. ${ }^{2}$ The first effect of the onset of ablation was to cause a thin icy crust to form at the snow surface. Subsequent melting took place beneath this icy crust, being greatest where the rock particles were most abundant; a "greenhouse" effect was set up. In the course of a few days melting proceeded to the ice surface, and the unsupported icy crust then collapsed. In Figure I the south-facing side of a snow-drift $25 \mathrm{~cm}$. deep has been destroyed by melting and the included dirt lowered to the ice surface. Figure 2 is a close-up view of this partly melted drift; in the remaining snow the rock particles have sunk a few $\mathrm{cm}$. only, as shown by the dark band in the snow-face.

As a result of the combined effect of the warm spring and the dust layer, ablation of ice on the lower part of Gilman Glacier probably started two weeks earlier in 1960 than in an average year.

\section{REFERENCES}

I. Hattersley-Smith, G. Studies of englacial profiles in the Lake Hazen area of northern Ellesmere Island. Journal of Glaciology, Vol. 3, No. 27, 1960, p. 614-15.

2. Lotz, J. R. Meteorological observations on Gilman Glacier, rg6o. Ottawa, Defence Research Board, 1961, p. 1. 


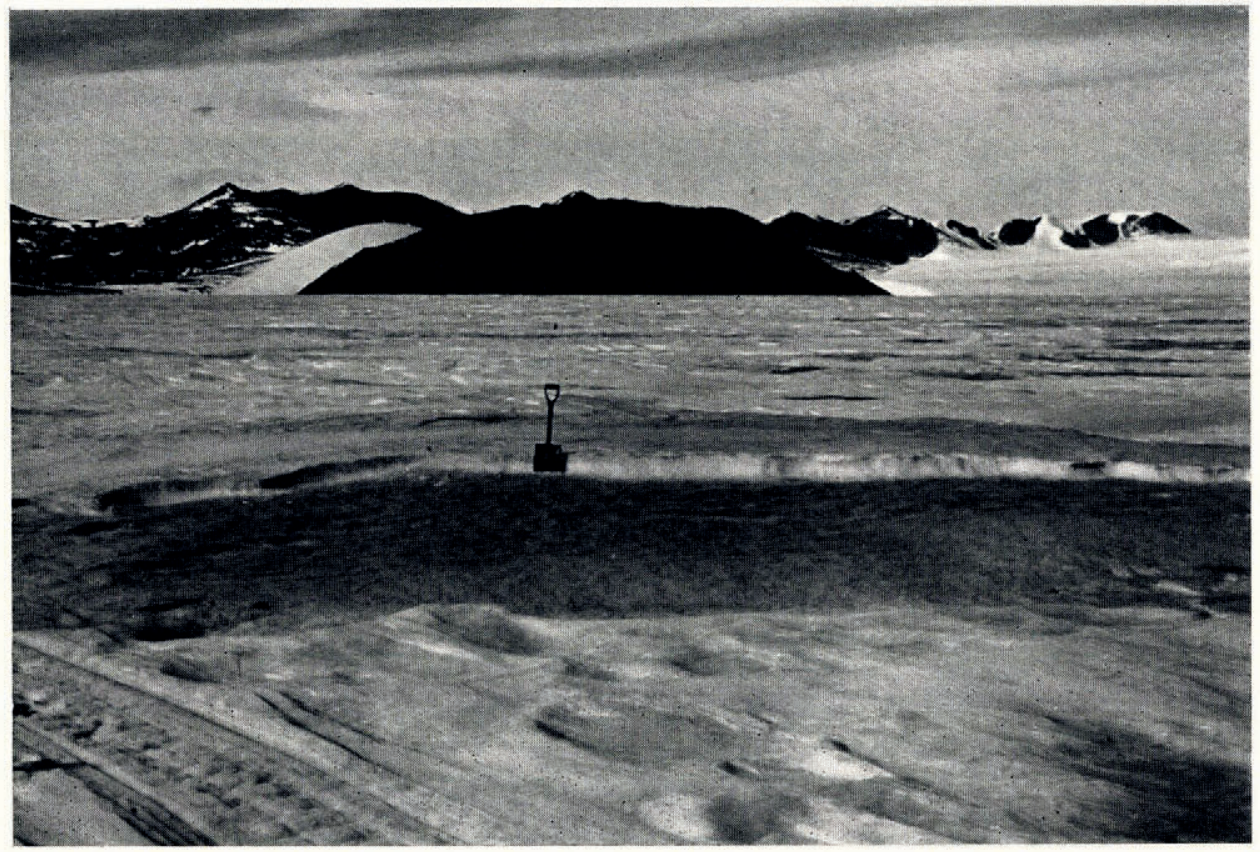

Fig. I. Gilman Glacier showing wind-hardened surface and effect of dust layer on ablation. The ice dome in left background was stripped bare of snow over most of its area in late May blizzard. 8 June 1960

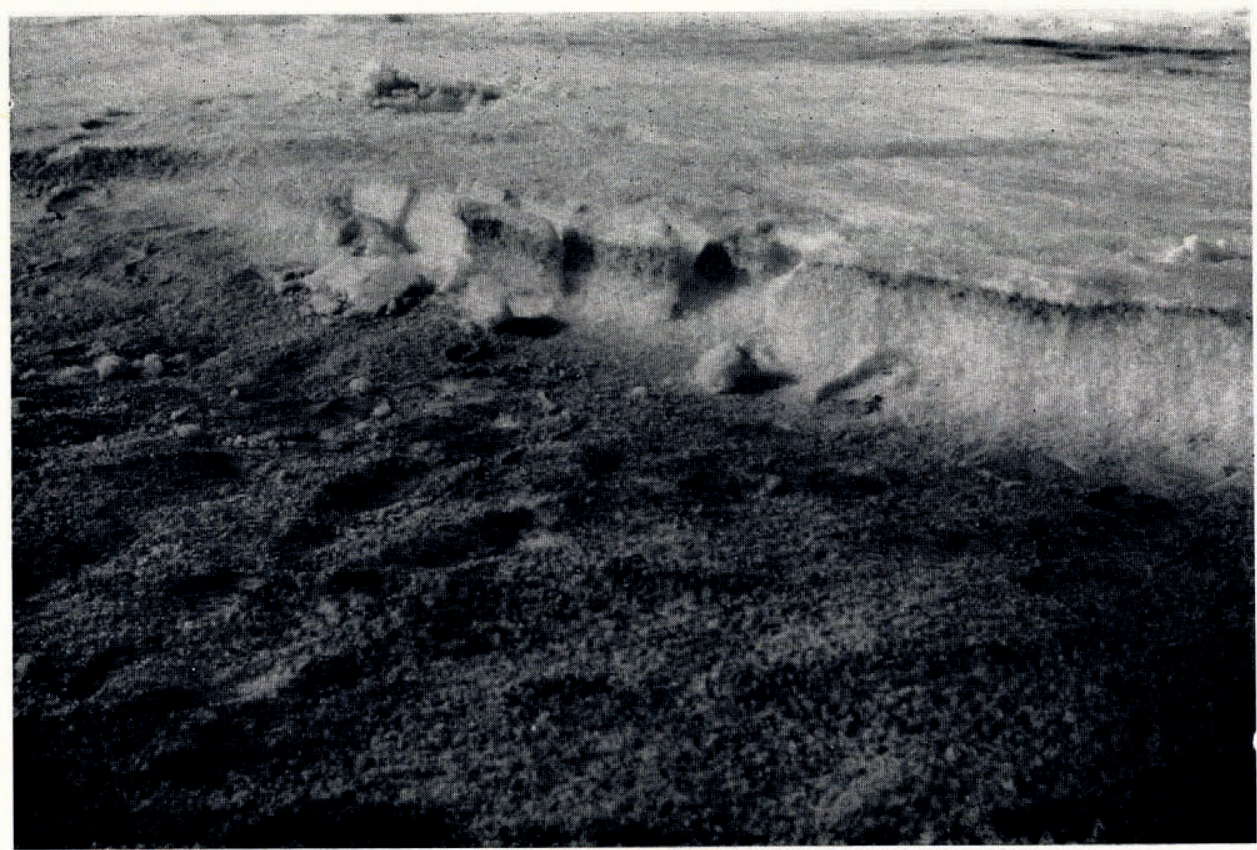

Fig. 2. Close-up view of snow-drift to show differential ablation due to wind-blown dust. 8 June 1960 